\title{
A REFLECTION ON BEING BORN BAD AND LAW'S OTHER VIOLENCES
}

\section{Nasser Rego*}

Patricia Williams' The Alchemy of Race and Rights, an indelible contribution to critical race theory and my own research, is a wilfully vulnerable and industrious account of her encounters with the law. ${ }^{1}$ This is my humble attempt to reflect on a fragment of my own work through her work's lens. As a doctoral candidate working with Palestinian Bedouin citizens from the Naqab in Israel, I'd like to narrate on the personal and particular to trouble and undo law's attempts to confine my own experience and that of my research's subjects to fixed categories from which law professes to reach universal legal truths. Williams' rather obvious assertion in the opening chapter, that "life is complicated", clues me in to how injecting the law with the personal, the subtle, the unenunciated in legalese, and the irrelevant under rules of evidence both deconstruct law's myths and force upon it the weight of that which it consistently evades. $^{2}$

First, a personal anecdote. Last month, my wife gave birth to a son. Predictably, being born a Palestinian in Israel, his naming was a politicized event. We named him 'Jaleel Noor'. Jaleel is the Arabic for Galilee, the region of his birth. The aim was to give him context, to emphasize that he is from this particular place, and not from any other, as the prevailing ethos in the Jewish state would undoubtedly tell him when he is old enough to understand. Noor means light, which is how we see him and all creation, how we'd like him to see himself, and how we intend, as parents, to create the space for his light to shine through.

His birth is a blessing. We embrace his arrival as we do (most of the time, anyway) the dirty nappies. We revel in the discovery of his daily discoveries. Yet, his birth also brings home harder realizations. It has forced many close to me to ask why raise him in a place where he is clearly marked out as 'racial other'? Where, from his registration at birth, through to the educational system and the town where he will grow up, his body is marked as racial other. The law, which pervades social life, constructs him similarly. There aren't any clear, easy answers, but certainly it has much to do with my fieldwork and my wife's home and family being rooted here.

And yet, it is precisely that the possibility is entertained that he can choose differently, a different habitus where he is not racialized in such explicit form, that hints to the privilege that Canadian citizenship accords him - the possibility to traverse boundaries that are too often closed, in varying degrees, for his fellow Palestinian countrymen.

One such compatriot is 'Nuri', a citizen of Israel and no other place, and whom I've interviewed extensively for my research. His whole life has centered on fighting for recognition of his family's historical lands in al-'Araqib in the Naqab in southern Israel, a fight that has often been staged within the theatre of the Israeli court.

And it is within the spectre of the court that Nuri learns to see himself and his community in a particular light. The Israeli court, as ideological actor and committed partner in a state-building project

LLM, PhD Candidate, Osgoode Hall Law School.

Patricia Williams, The Alchemy of Race and Rights (Cambridge: Harvard University Press, 1991).

Ibid at $10-11$. 
that necessarily excludes racial outsiders, contributes to constructing the Fanonian 'white mythos' around Palestinians, which means that it weaves their bodies from "a thousand details, anecdotes and stories". ${ }^{3}$ As racial others under Israeli sovereignty, the courts tell us to see Palestinian citizens of Israel as "cultural others" who pose a latent security threat, while citizens from the Naqab, like Nuri, are regularly framed within the strictures of criminality. With regard to Palestinians from the Occupied Palestinian Territory, the courts repeatedly remind us of their proclivity to terror. ${ }^{4}$ In many ways, the legal binary of "white equals good, and black equals bad", one that Williams' writes has stretched to include a few 'good blacks' in the US, in many ways persists in 2012 in Israel. ${ }^{5}$

Which begs the question, where do we begin our break from this binary? By demonstrating that Nuri can also be a 'good Arab' or that the Bedouin community can also possess traits that are 'not that bad'? Yet, do we at the same time not perform self-denial and reify racial hierarchies by trying hard to be exceptions to the rule? Or, in tune with a politics of seeing the noor (light) in all, of the ethical turn to the other and the ever striving but possibly never succeeding attempt at justice, can we operate external to this binary and challenge the very foundations from which it emanates?

I refer here to exposing the phenomenon, largely unenunciated in law, of 'structural violence'. Structural violence is systemic violence by those that belong to a certain social order directed at other persons not of the same order, preventing them from achieving their potential. Its source and its subjects cannot be identified, making it difficult to name, the effects seem 'wrong' and yet nobody's fault and the suffering of those affected is elided. The difficulty in naming structural violence is an historical amnesia that prevents current acts of structural violence to be associated with, or to be seen as an effect of, a specific perpetrator or historical referent. ${ }^{6}$

That in law the facts of the case are to be precise and exact, that evidence be relevant, and the parties identifiable, render law deficient in apprehending and recognizing structural violence. Instead, law's exclusive categories and binaries from which decontextualised universal truths are created and spoken by 'objective', 'authentic' voices effects an historical amnesia, which in turn enables structural violence. Naming structural violence by telling of the personal and particular both provides historical context and forces dehiscence of law's binaries. ${ }^{7}$

How does historical amnesia manifest in the law? In petitions concerning land rights of Palestinian Naqab Bedouin, the court has shown a lack of engagement around the contested legal status of Naqab land. A land settlement process initiated in the 1970s is still ongoing, meaning that the authorities have officially registered the fact that there are contested claims on land ownership, yet the courts continue to refer to the Naqab Bedouin collectively as 'the dispersion'. An engagement with the land's contested status would preclude the court's use of labels of illegality, such as 'the dispersion', 'squatters' or 'interlopers' when referring to the community.

Frantz Fanon, Black Skin, White Masks (New York: Grove Press, 1967) at 89-119.

$4 \quad$ Nasser Rego, "Reading Fanon in Palestine/Israel", Jadaliyya (April 9 2012)

$<$ http://www.jadaliyya.com/pages/index/4972/reading-fanon-in-palestine-israel $>$.

Williams, supra note 1 at $115-6$.

6 Paul Farmer, (2004) “An Anthropology of Structural Violence", Sidney W. Mintz Lecture (2001) 45:3 Current Anthropology 305-25; Carmela Murdocca, “"There is Something in that Water': Race, Nationalism and Legal Violence” (2010) 35:2 Law and Social Inquiry 369-402.

Williams, supra note 1 at $8-9$. 
Second, the violent events of 1948 are similarly foreclosed. Therefore, the courts make no reference to the fact that roughly $90 \%$ of Palestinian Bedouin from the Naqab were expelled or forced to flee, while those remaining were forcibly concentrated in a closed reservation under Military Administration rule with basic civil liberties of freedom of movement, freedom of association and the right to property denied. Forced concentration in the reservation enabled large scale land expropriation and is therefore a principal cause of the land conflict between the Naqab Bedouin and the state today.

The task seems to be sketching the links between the land's contested status and the violent events of 1948 and current forms of structural violence, which are almost never named, and therefore cannot be apprehended by law. Naming the particular and personal would mean attempting to make the court's ears catch the violence of Nuri losing fifteen family members to roadside accidents because his village is 'unrecognised' by the state and so unpaved. It is the violence of being ordered by the court, in a language he doesn't expertly grasp, to pay for the expenses the authorities incurred in demolishing his tent in al-"Araqib. It is the violence of the permanent anxiety that is his company, like when he was on an indigenous solidarity visit to the US a few years ago. He awoke one night to the nightmare that just as he was about to partake of a 'mansaf' (chicken and rice) dinner, it disappears. He interprets the dream to mean that his crops in al-'Araqib, which he cultivated, had been destroyed, preventing him from enjoying the product of his labour. He returns the following week and finds that the authorities had indeed destroyed his crops. It is about being estranged from wife and children because the costs of being a social justice activist preclude him from also being a husband and father. It is the violence of being called to approach the bench by the district court judge in his land ownership case over plots in al'Araqib, a case he subsequently lost, to be told, "I will assist in making a compromise between you and the state. You are old. You don't have much longer to live. Who is left after you to follow on the case? Grab this opportunity - a bird in hand is worth two in the bush".

The undertaking for Nuri and others (including, quite inevitably, Jaleel Noor) that pursue legal struggle is to think of not just how to make suffering and violence in its explicit, elephantine forms be apprehended by the law, but to name the more nuanced, particular forms of structural violence that better capture the spectrum of human suffering. Because the 'illegal' is never only an illegal, he is also a father and husband, a farmer and a griever. It is the everyday labour of raising the same in legal commentary, op-eds, lectures, symposiums as this one, and its weaving into petitions and trial proceedings. Doing so would force a weight on the law so great that it could no longer commit itself to historical amnesia and still call itself by its name. 